\title{
Development of State-Owned Enterprises of Transport Industry in Latvia
}

\author{
Māris Plūmin̦š ${ }^{1}$, Deniss Ščeulovs ${ }^{2}$ \\ ${ }^{1,2}$ Riga Technical University
}

\begin{abstract}
The transport infrastructure and state-owned enterprises (SOEs) have a significant effect on competitiveness of transport industry, and indirectly determine the business environment in related sectors. In Latvia, all transport related state strategies and policies are developed, controlled and overviewed by the Ministry of Transport. Eleven companies are engaged in commercial/non-commercial activities, and evaluated whether the liberalization of certain activities would provide efficiency among SOEs in the transport industry of Latvia, given the sectoral weight and share of State involvement and control of the industry.

There is limited and contradictory debate to what extent the Latvian state should involve in business activities of transport industry, and how to balance the multiple interests and targets of business, society and politics.

The present research is based on the scientific papers, official documents of the World Bank and OECD (Organisation of Economic Cooperation and Development), company websites and annual reports.
\end{abstract}

Keywords - Business, competitiveness, entrepreneurship, stateowned enterprises, transport industry.

\section{INTRODUCTION}

The EU main challenges in the transport industry are sustainable, integrated and appropriate quality and cost of transport infrastructure and services. The main role of the industry is to provide physical movement of freight and passengers seamlessly across the common market without barriers and fragmented networks of all transport modes. Transport industry is of paramount importance in geographic cohesiveness, competitiveness and development that reduces disparities and accessibility among different regions of Europe and new member countries. At the same time, the pressure to reduce environmental impact and scarce resources is needed in increased capacity and efficient performance is required leading to modern multimodal transport solutions (HORIZON 2020, 2015).

The goal of the research is to summarise the key data and company profiles providing insight into state control and the particular areas, which are regulated and controlled by the government, as liberalization of market conditions should improve quality, reduce costs and positively impact business environment in the given transportation sectors as part of the public sector.

Hypothesis: State has a clear vision of the goals and strategy of efficient use of its assets in the transport industry.

There are several steps of the paper development to fulfil the main tasks: provision of main concepts and definitions, state reasons for ownership of assets in the transport industry provided by the regulatory framework, degree of regulation in SOEs of the Latvian transport industry, their descriptive profiles, including assets value, number of employees and turnover. The summary of main SOEs services and their description provides a detailed overview of the commercial/non-commercial activities and current degree of market regulation and competition.

Mainly due to the fact that the transport industry (particularly infrastructure) is a state-controlled area in most of the OECD countries, inefficient management practices, unsustainable infrastructure charge, cost models and regulations are just some issues impairing the vitality of SOEs in the transport industry in Latvia. The article overviews the EU, WB, IMF and OECD documents, as well as academic research in the field. At the moment of writing the article, Latvia is not yet the OECD member, but as a candidate state it is included in research papers.

\section{MAIN SOE CONCEPT AND DEFINITIONS}

"State ownership may refer to state ownership or control of any asset, industry, or enterprise at any level, national, regional or local (municipal); or to common (full-community) non-state ownership. It is a business that is either wholly or partially owned or operated by a government. State-owned enterprises are common throughout the world." (Clarke \& Kohler, 2005).

"First, there are state-owned enterprises (SOEs), also called government owned corporations, which are defined as "legal entities created by a government to undertake commercial or business activities (are engaged in the provision of essential infrastructure and related services which are vital to the competitiveness of the economy (e.g., electricity, gas, airports, seaports, rail, bus, telecommunications, etc.). on behalf of an owner government. The defining characteristics are that they have a distinct legal form and they are established to operate in commercial affairs" (Business dictionary, 2015).

There are several SOE definitions, but following Aharoni (1986, p. 6) we refer to SOEs as productive firms, which are firms that produce "goods and services for sale, this function distinguishes SOEs from other public sector activities that are more in the nature of public goods (such as defence, police or courts)". The World Bank, however, uses the following definition: SOEs are "government owned or government controlled economic entities that generate the bulk of their revenues from selling goods and services" (World Bank, 1995). 
At the national level, there are a multitude of definitions of an SOE. Most of these definitions have been developed for administrative or national budget purposes or by state ownership agencies. (Many of these definitions tend to be rather narrow in scope. From an analytical viewpoint, this is problematic as it means that neither SOEs held at the subnational levels nor unincorporated entities (according to national accounts definitions, "quasi-corporations") would normally be included. In some cases, it also means that enterprises with a government ownership of less than $50 \%$ would be excluded (OECD, 2003). This is a factor that provides the misleading figures of the state presence and direct or indirect influence of certain sectors.

Even if there is no general agreement on what is an SOE, there is, however, some consensus on the key factors that distinguish SOEs from privately-owned firms:

- "SOEs generally face softer budget constraints than private enterprises because of (a) the possibility of infusions of government cash; and (b) cheaper financing due to perceived government guarantees;

- SOEs are generally charged with the pursuit of a number of non-commercial objectives;

- Even where SOEs are not used by government to pursue public policy goals, they are shielded from the risk of takeovers and in practice will often be less commercially oriented than other companies because they are more easily captured by insider groups such as management or unionised staff (OECD, 2003).

The three main categories of SOEs are:

(1) Statutory corporations which run close to or as part of a government department;

(2) Fully incorporated state-controlled companies;

(3) "Listed SOEs with a minority share floated on stock markets. The latter category is becoming more and more widespread and, as they are subject to both general company law, and securities laws, listing requirements etc. is much less problematic from a competition viewpoint. The second important consideration refers to the fact that adverse effects on competition due to the presence of an SOE in the market may not be necessarily related to the public ownership of SOEs. There may be other factors (e.g., concentrated market structures, market failures, natural monopolies, legal monopolies, etc.) that would equally apply to private companies in like circumstances and generate the same incentives to adopt anti-competitive strategies." (OECD, 2010).

When markets are unable to efficiently allocate products or resources to the most welfare-enhancing use, government officials are compelled to intervene to address these inefficiencies using an array of instruments such as taxation, regulation, or direct ownership; the latter instrument results in the creation of SOEs (Levy, 1979; Lindsay, 1976; and a review in Lawson, 1994).

Three commonly accepted assumptions about state-owned firms could be applied as the basis to understand statecontrolled firms, which are described briefly as follows:

(1) The government maximises social welfare,

(2) The government pursues political goals, and
(3) Politicians are also interested in maximising their own incomes, including bribes (e.g., Shleifer, 1998; Boycko, 1993 and 1996).

Over the years, the rationale for state ownership of commercial enterprises has varied among countries and industries and has typically comprised a mix of social, economic and strategic interests. Examples include industrial policy, regional development, the supply of public goods and the existence of so-called "natural" monopolies. Over the last few decades, however, globalisation of markets, technological changes and deregulation of previously monopolistic markets have called for readjustment and restructuring of the stateowned sector (OECD, 2005); as a result, society is demanding better performance, transparency, efficiency and better results with less resources.

Although large SOEs, mostly national champions in their respective sectors, retain their state affiliation and are thus subject to government influence, private entrepreneurial firms are increasingly operating in a free-market environment (Tan, 2002), reflecting many advantages of private ownership over state control (Perotti et al., 1999). Many studies show that the performance of enterprises in regulated industries is higher than that of enterprises in competitive industries (D'Souza \& Megginson, 1999; Megginson \& Netter, 2001). Specifically, when government enforces regulations in some industries, such as public utilities, transportation, metallurgy, and heavy industry, it is generally in the nature of market dominance and low competition, resulting in higher monopolistic profits. To some extent, firms in regulated industries may achieve better performance after privatisation. The market competition to the public sector is "considered leading to improved efficiency and customer responsiveness" (Graham, 1997; Lane, 2002) and lowering the budget expenses (Talbot, 2001). Therefore, compared with family-controlled firms, state-controlled firms are likely inefficient (e.g., Shleifer, 1998). The managers are prone to easy corruption, and a minority of shareholders are easily expropriated by government or managers in the forms such as diverting resources away from the firm by government, or simply corruption or bribery by managers (Shleifer, 1998).

Pursuing multiple aims forced the managers of SOEs to sacrifice economic aims to achieve the others (Basu, 2008). "The above mentioned SOE disadvantages lead to the governance, accountability and sustainability issues in most of the countries. State ownership has been defended on the grounds of various types of market failure, and it has been regarded as an instrument for the attainment of non-economic goals such as the need for public control over natural resources, regional policies, employment or social issues, etc. (Grout \& Stevens, 2003).

While there has been a general tendency within the past decades to reduce the overall level of state ownership through privatisation efforts, SOEs have not been eliminated, and many are growing stronger (Bortolotti \& Faccio, 2009). Recent studies looking at the ownership patterns of firms within emerging economies, especially in China and Russia, have concluded that state ownership of firms will not 
disappear in the near future (Lin \& Milhaupt, 2011; Okhmatovskiy, 2010; Puffer \& McCarthy, 2007). In effect, SOEs are actually on the rise in some countries, such as Russia and Venezuela, where the privatisation movement has been reversed and where certain SOEs acquire some of their private competitors (Business Week, 2011; Economist, 2012; Puffer \& McCarthy, 2007).

POEs (privately owned enterprises) contrary to SOEs have clear goals of the stake holders, the unclear investment and return projects are the main reasons of SOE transport infrastructure projects, in order to solve this inefficiency the PPP (private public partnership) is the cutting edge between financial viability and public welfare.

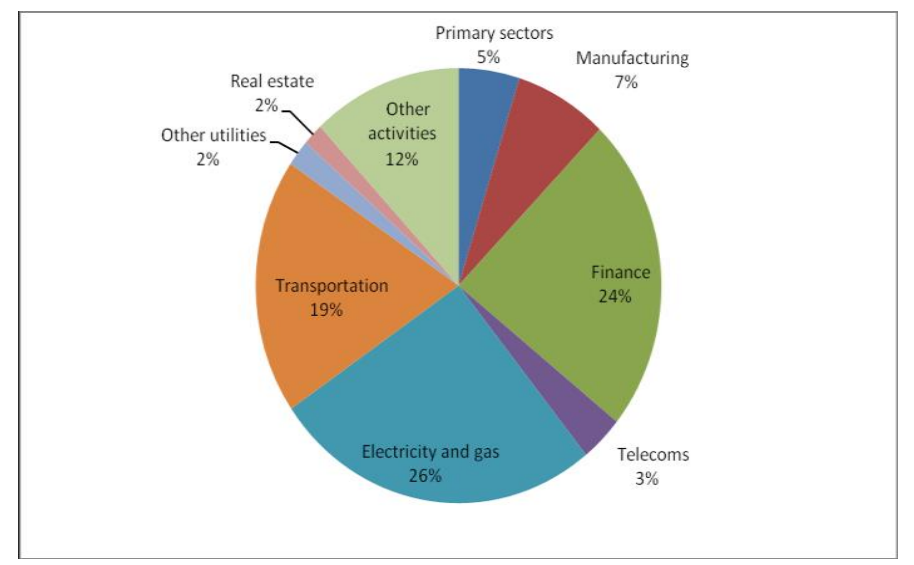

Fig. 1. Sectoral distribution of SOE sector, by company value (total OECD) (Christiansen, 2011).

\section{THE MAIN REASONS OF ESTABLISHING SOES}

In general, governments are one of the major stake holders in their own country. There are not strict rules or preconditions of state engagement in commercial activities and establishing SOEs, but more often the state becomes an entrepreneur in order to support sectors of strategic importance, develop less developed regions and areas, protect the interests of society which would not be possible to safeguard in conditions of free competition. The main reasons of establishing SOEs are as follows:

- National security support;

- Stakes in industries, where there is lack of private investors due to uncertain outcomes and profit potential;

- Bulky projects associated with significant investment, but return and property rights are uncertain;

- Involvement in industries, which are out of date, or development is hindered by natural hazard risks;

- Involvement in enterprises, where it is directly or indirectly possible to reduce the social inequality and increase the social stability;

- Safeguarding the sustainability of new sectors;

- Development of less developed regions.

There are numerous reasons for establishing or retaining public enterprises. Jones and Mason (1982) categorised the reasons as follows: ideological predilection, acquisition or consolidation of political or economic power, historical heritage and inertia, and pragmatic response to economic problems. As the main regulator of the economy, the state is not only the source of formal institutions (North, 1990), but also a significant factor in many economies (Hou \& Moore, 2011; Okhmatovskiy, 2010). In many countries, the state has an ownership stake in numerous firms (Aharoni, 2000; La Porta, Lopez-de-Silanes \& Shleifer, 1999). There is broad consensus among economists that shifting from public to private ownership tends to increase efficiency and profitability, especially in areas where competitive pressure can be strong (Meggison \& Netter, 2001). The main purpose of this article was to identify the main factors and principles why the Latvian state engages in entrepreneurship and maintains control of the assets in transport SOEs. Scope of this research is limited to the analysis of services provided by Latvian SOEs in transport industries since transport comprises a significant share of national GDP, $11.3 \%$ in 2013 (Ministry of Economy, 2014).

According to the Baltic Institute of Corporate Governance (2012), "SOEs are fundamentally important to the Baltic economy. They provide crucial services to industry and the public. When things go well, they can provide a solid base for economic and social development, contribute significantly to state budgets, and be an important tool to achieve government policies. When things go wrong, they can become a crushing financial and political burden. The public interest in the performance of SOE is thus often acute."

"SOEs in competition with private sector businesses, or in areas where private sector businesses could potentially compete is impacting business environment. The experience of OECD countries illustrates that in these competitive or potentially competitive markets, several possible sources of competitive distortions can arise because of advantages some public sector businesses have due to their government ownership. The traditional divide between public and private sector services has become blurred in recent decades. Over time, resources such as large-scale finance, capital assets, and expansive networks, have become increasingly accessible to private sector organisations" (OECD, 1998). Contrary views are also present; a review of corporatisation "after two decades of experimentation" O’Flynn (2007) is perhaps timely to understand the environment and context in which SOEs operate, examine the financial and economic returns, and consider the potential for entrepreneurial and strategic activity in the public sector context of SOEs. According the data of International Labour Organisation (ILO), Latvia has one of the leading positions of public sector employment - $32 \%$ against the OECD average of $22 \%$, which is also explained by the level of state control of transport industry in Latvia. "State involvement in the economy is considerable, notably in the network sectors. The administrative burden on start-ups, sole proprietors and corporations is above the OECD average" (OECD, 2015).

In this respect, management of the public sector has been considered from various perspectives (Savas, 1981) with a common divide being government's role as one of "rowing" versus "steering" (Morris \& Kuratko, 2002; Osborne \& Gaebler, 1992), as explained below. Despite continued debate on government's role of rowing versus steering, not everyone 
sees the alternatives as mutually exclusive. Research by the World Bank indicates that a combined programme of privatisation and corporatisation (i.e., incorporating government departments with a commercial focus such that they become separate legal entities such as state-owned enterprises) is the most effective approach in managing the public sector (Shirley, 1999).

According to the International Labour Organisation (ILO), "Public sector employment covers all employment of general government sector as defined in the System of National Accounts (SNA) plus employment of public corporations". Public corporations are legal units producing goods or services for the market, which are controlled and/or owned by government units.

The authors agree that SOEs or also called government corporations are an important part of economy and are going to keep the control and ownership in strategic industries and sectors. The open question is what and how to do it in the best way to all shareholders involved. The share and weight in the industry, as well as industry composition and regulatory control are just some aspects to discover in this paper.

\section{PRIVATISATION ARGUMENTS}

According to Dewenter and Malatesta (2001), while for managers of privately owned entities the main goal is defined as shareholders' wealth-maximization, privatization leads to refocusing goals and implementation of strategies that help achieve them. Also, as noted by Vickers and Yarrow (1988), transfer from the public sector with the introduction of shares creates market for corporate control. If this market functions in an efficient way, privatisation should produce powerful incentives for increasing (internal) efficiency. Furthermore, even when confusion about the different targets was absent, shortcomings in the governance and financial structure of SOEs together with the lack of motivating market competition combined to work against their efficient operation (Vickers \& Yarrow, 1988).

In theory, SOEs are owned by all citizens in a country. However, in practice they are controlled by state bureaucrats and politicians. The firms' citizen-owners have no corporate governance mechanisms to monitor the running of SOEs, which may be run according to politicians' goals (CuervoCazurra \& Dau, 2009). Thus, in addition to social and economic performance goals, SOE managers must also balance bureaucratic and political interference from such officials (Lawson, 1994). Officials' goals typically support their own political interest, but do not necessarily support social or economic performance - especially since profits go into the governments' coffers, not to the bureaucrats themselves (Shleifer \& Vishny, 1994).

The issues of deregulation, competition, and privatisation are particularly relevant given the increasing demand for accountability within government, from both a financial and social perspective (Carnegie \& West, 2005; White, 2005). The main challenge is to provide the efficient playing field in the industry and balance between agency costs and control and management of contracting activities of certain tasks.

\section{A. Other Forms of Restructuring the SOEs in Transport}

According to the European Bank for Reconstruction and Development, "where the reform process is less advanced, and ownership and operation are retained by the public sector, the challenges centre on the need to improve the efficiency of railway and road management and the implementation of commercially-oriented contracts based on the principles of transparency and accountability. Where infrastructure and operations remain within a single entity, mainly in the rail sector, the Bank generally supports vertical separation to increase efficiency. By separating fixed assets for operations, for example, the possibility to implement track access regimes to new operators is made possible. It opens up the potential to allow new operations to be introduced as well as private freight operations, which should improve efficiencies and provide more market-responsive services" (EBRD, 2013).

\section{B. Developing and Issuing an Ownership Policy Defining the Objectives of State Ownership}

This will help Latvia avoid the situation where SOEs have no or excessive autonomy in defining the nature and extent of their public policy objectives. Latvia has made the step in the right direction and established the single state asset over viewing state organisation "Pārresoru koordinācijas centrs", responsible for setting up objectives, monitoring and evaluation of SOE performance and governance issues.

Latvia's previous decentralised SOE ownership structure is ineffective and exposes SOEs to the risks of mismanagement and abuse. Ownership of enterprises needs to be conducted on a whole-of-government basis, rather than at the unchecked discretion of individual ministries.

There should be clear separation between the state's ownership functions and other state functions that may influence the conditions, for state-owned enterprises, particularly with regard to market regulation (OECD, 2015).

On the other hand, other authors present evidence justifying the contrary view that state-owned enterprises are no less efficient than private firms. As Vickers and Yarrow (1988) notice, evaluation of the relative performance of private and public firms is not comprehensive because of the existence of state monopolies in utility industries such as gas, water, electricity, telecommunications, meaning that there are no domestic benchmarks against which the performance of stateowned entities could be assessed. Similar views are shared by Kole and Mulherin (1997), Caves and Christensen (1980), but most of these authors argue that the "inefficiency of government enterprises stems from the isolation from effective competition rather than public ownership".

\section{SOE DEVELOPMENT IN LATVIA}

Large public involvement in the economy poses regulatory challenges, and a number of state-owned enterprises have been involved in competition cases. More than $6 \%$ of total dependent employment is in state-owned enterprises, which would rank Latvia just after Norway, France and Slovenia, which are the OECD countries with the highest shares of employment in public companies. SOEs have sub-par 
governance structures, not least because boards of directors for all SOEs were - with a few exceptions - abolished in 2009 (OECD, 2015).

The state enterprise ownership function is decentralised and the separation between ownership and other functions is blurred, making oversight and ensuring a level playing field challenging. No regular aggregate reporting is in place, and monitoring mechanisms are weak (OECD, 2015b forthcoming). Some SOEs are "strategic", i.e., not to be privatised (e.g., Riga airport authority, Latvian Post, Latvian Railways). They maintain a monopoly position and are prone to abuse it, as illustrated in rulings of the competition authority.

A legislative package of reforms of SOEs that has come into force this year ("Public Persons Enterprises and Capital Shares Governance Law") goes some way towards addressing these shortcomings. Notably, it reintroduces boards to the biggest SOEs; establishes an entity coordinating state enterprise ownership (the Coordination Institution) and requires annual aggregate reporting. Nevertheless, the implementation of the new SOE corporate governance function will be the key (OECD, 2015b forthcoming). Besides, in line with the OECD Guidelines on Corporate Governance of State-Owned Enterprises, boards of directors should be reintroduced for all commercially-oriented companies, with clear selection and nomination procedures; annual aggregate reporting should become the norm, and large or listed SOEs should adhere to high quality internationally recognised accounting and auditing standards. Competition issues in the network industries mainly result from poor connectivity of the infrastructure and incumbents that continue to dominate the market. Most of the network sectors remain concentrated and have a high degree of public ownership (Karnitis \& Virtmanis, 2011), but progress is being made. The unclear delineation between SOE commercial and non-commercial objectives was one of the major critiques included in the 2009 State Audit Office Recommendation for improving SOE corporate governance. The recommendation was based on the Office's annual audits of ministries' books, including subsidies to SOEs in ministries' portfolios. The recommendation also included a call for the government to clarify its state enterprise ownership policy and to address the corporate governance risks posed by the lack of SOE boards of directors.

\section{A. Legal Framework in Latvia for SOEs}

Under Latvia's legal framework for SOEs, the state may perform commercial activities if public interests are not met by privately owned enterprises. This principle underlines the government's enterprise ownership rationale, which is expressed under Section 88(1) of the State Administration

According to Structure Law 81 under this provision, the state may establish or continue to own or control a commercial enterprise:

- If the market is not able to ensure the implementation of the public interest in the relevant field;

- In a sector in which a natural monopoly exists, thus ensuring the public availability of the relevant service;
- In a strategically important sector;

- In a sector, for the development of the infrastructure of which large capital investments are necessary; or

- In a sector, in which, in conformity with the public interest, it is necessary to ensure higher quality standards.

While some Latvian SOEs operate in competitive markets with commercial objectives, all SOE activities must be undertaken "in the public interest", and, as a result, most SOEs also have social and public policy objectives. SOE objectives are formally set via:

"Laws, state regulations, and approved sectorial development concepts, strategies and other documents governing sectorial development" as per Art. 19.3 of the Law on State and Local Government Capital Shares and Capital Companies. This provision also tasks the state's representative (either a Ministry's state secretary or the head of a public institution) with ensuring that the SOE fulfils these goals.

"Delegation of administrative tasks" by the state to an "authorised person" (i.e., an SOE) via the so-called delegation contracts, as per Chapter 5 of the State Administration Structure Law. These contracts, entered into between SOEs and line ministries or public institutions, must include a description of the specific delegated task and "quality evaluation criteria for the performance of the task, but, if the subject-matter of the contract is a one-time task, also the results to be achieved" (Art. 46.2, 5). Delegation contracts are normally valid for up to three years, and contracts lasting longer than three years must receive the Cabinet approval.

Objective-setting, more generally, is usually guided by sector-specific, non-legally binding policy documents for SOEs that set overall sectoral objectives. Responsible Ministries develop these policy documents, which must then receive the Cabinet approval. Latvian authorities provide, as an example of SOE objective-setting, state-owned theatres and concert organisations, whose objectives are determined by delegation contracts between the SOEs and the Ministry of Culture, as well as by the Law on Cultural Institutions (Art. 23.2) and the sectorial policy document "State Culture Policy Guidelines 'Creative Latvia' 2014-2020” (OECD, 2015).

The report provides detailed information on the financial performance of companies that are fully or partly owned by the government. BICG experts have analysed the profitability of companies in the energy, telecommunications, forestry, transport, real estate, healthcare and other sectors. According to the compiled data, the Latvian state is a shareholder in altogether 142 companies with their aggregate turnover comprising $18 \%$ of Latvia's GDP in 2009. In per capita terms, the value of state-owned shares and assets is 1,646 LVL. The total value of state-owned assets is 3.68 billion LVL, including state shareholdings in companies 2.06 billion LVL worth. The balance sheet total of SOEs is 7.15 billion LVL. In 2009 SOEs contributed 185 million LVL to the state budget by dividend payouts; the number of employees is about 53 thousand (Mortensen, 2009).

As of end-2012, Latvian authorities report that the state fully owns 69 SOEs and owns more than $50 \%$ shares in other 
eight enterprises and owns between $10 \%$ and $50 \%$ shares in 17 enterprises.

The government reports that it holds a minority (less than $10 \%$ ) share in 51 commercial enterprises. Moreover, Latvian SOEs hold shares in 114 other enterprises, with ownership ranging from $0.01 \%$ to wholly owned subsidiaries. Latvian SOEs take one of two legal forms: state-owned joint stock companies ("akciju sabiedrība"; JSC) and limited liability companies ("sabiedrība ar ierobežotu atbildību"; LLC). There are no statutory corporations in Latvia's SOE sector (OECD, 2015).

TABLE I

AN OVERVIEW OF THE MAJORITY OF COMPANIES OWNED BY LATVIAN GOVERNMENT (SOURCE: OECD, 2014)

\begin{tabular}{|l|c|c|c|}
\hline Main sector & $\begin{array}{c}\text { Number of } \\
\text { enterprises }\end{array}$ & $\begin{array}{c}\text { Number of } \\
\text { employees }\end{array}$ & $\begin{array}{c}\text { Value of } \\
\text { enterprises } \\
\text { (EUR } \\
\text { million) }\end{array}$ \\
\hline Total & $\mathbf{7 4}$ & $\mathbf{5 2 2 4 0}$ & $\mathbf{3 7 0 2 . 8}$ \\
\hline $\begin{array}{l}\text { Primary } \\
\text { sectors }\end{array}$ & 1 & 1234 & 306.7 \\
\hline Manufacturing & - & - & - \\
\hline Finance & 5 & 2230 & 351.3 \\
\hline Telecoms & 5 & 3138 & 338.7 \\
\hline $\begin{array}{l}\text { Electricity and } \\
\text { gas }\end{array}$ & 2 & 4517 & 2012.6 \\
\hline Transportation & 6 & 16071 & 220.4 \\
\hline Other utilities & 1 & 4470 & 8.2 \\
\hline Real estate & 5 & 960 & 151.1 \\
\hline $\begin{array}{l}\text { Other } \\
\text { activities }\end{array}$ & 49 & 19620 & 313.8 \\
\hline
\end{tabular}

The above-mentioned data of 2009, 2012, and 2014 show the stable positions of SOEs in the Latvian economy; we may presume that such SOE growth and development trend will remain due to the different factors described before.

We can conclude that a number of SOEs and their controlling assets, as well as employees are significant factors, which emphasise the importance of the topic.

\section{B. Basic Principles how SOE Board Determines the Tariff or Prices for Their Products or Services}

- $\quad$ Based on costs and market competition conditions;

- Based on service calculations and additional rate of indirect costs, differentiate services;

- Based on calculating actual costs and evaluating the market situation;

- Demand, market situation, customers; ability to pay;

- Considering hourly costs of technical experts;

- Lower price than interest rate determined by the Treasury of Latvia;

- The cost method according to law.

In the transport industry of Latvia, a majority of services are provided with commercial objectives to make profit, although some services are assigned by the state (according to the Cabinet of Ministers). In some cases, PUC (the Public Utilities
Commission) or other institution is involved (Kronbergs \& Cukste, 2012). Empirical studies reveal that Latvia is lagging in development of sustainable transport infrastructure services due to inapropriate cost, charge and financing models, which may result in deterioration of transport infrastructure.

\section{SOES IN TRANSPORT INDUSTRY}

Transportation plays a connective role among the several steps that result in the conversion of resources into useful goods in the name of the ultimate consumer. It is the planning of all these functions and sub-functions into a system of goods movement in order to minimise cost, maximise service to the customers that constitute the concept of business logistics. The system, once put in place, must be effectively managed (Fair et al., 1981).

Therefore, transportation is the basis of efficiency and economy in business logistics and expands other functions of logistics system. In addition, a good transport system performing in logistics activities brings benefits not only to service quality but also to company competitiveness (Tseng, 2005)

The role of infrastructure for economic development has been well documented in the literature (Ashauer, 1989; Munnell, 1990; World Bank, 1994; Calderon \& Serven, 2003; Estache, 2006; Sahoo \& Dash, 2008; 2009). Infrastructure development, both economic and social, is one of the major determinants of economic growth, particularly in developing countries.

According to Christiansen (2011) and Kowalski et al. (2013), $19 \%$ of world SOEs is located in the transport industry according to company value.

In Latvia, this is the largest sector in terms of the number of people employed by SOEs in transportation (23 839 employees). The transportation sector also has the highest aggregate SOE turnover (EUR 959 million). Energy sector SOEs make up the largest share of aggregate SOE value (35\%), followed by transportation (26\%) and telecommunications (14\%). The forestry and telecommunications sectors had the highest net margin profitability in 2009 (Mortensen, 2009).

There are several SOE ownership function models in OECD countries. Latvia has chosen the sectoral management policy of SOEs, although gradually according to OECD, and World Bank recommendations for reforms Latvian SOEs gradually transfer management and supervision functions to central management and governance structure of CSCC (CrossSectoral Coordination Centre, 2015).

At present, Latvia has a decentralised SOE ownership structure, under which Latvian SOEs are overseen and managed by 11 ministries and three public institutions.

\section{Strategy of the Ministry of Transport}

Transport sector includes railways, road traffic, maritime and aviation, as well as passenger carriage and transit branches. Road transport and traffic safety are under responsibility of the road traffic branch. The branch of communications includes electronic communications and the post. 
TABLE II

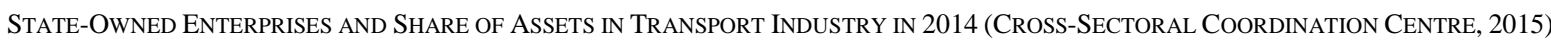

\begin{tabular}{|c|c|c|c|c|c|c|}
\hline $\begin{array}{l}\text { State-owned } \\
\text { enterprise }\end{array}$ & Sector & $\begin{array}{c}\text { Turnover } \\
\text { 2014 } \\
\text { EUR'000 }\end{array}$ & $\begin{array}{l}\text { Profit/losses } \\
2014 \text { EUR'000 }\end{array}$ & $\begin{array}{l}\text { Total assets as } \\
\text { of } 31 \text { December } \\
2014 \text { EUR'000 }\end{array}$ & $\begin{array}{l}\text { Number of } \\
\text { employees }\end{array}$ & $\begin{array}{c}\text { Share of } \\
\text { assets }\end{array}$ \\
\hline $\begin{array}{l}\text { VAS “Latvijas } \\
\text { dzelzcel̦šs” (holding) }\end{array}$ & $\begin{array}{l}\text { Railway operations and } \\
\text { infrastructure, real estate, IT }\end{array}$ & 440898.0 & 1161.0 & 972032.0 & 12316 & $100 \%$ \\
\hline $\begin{array}{l}\text { AS “Air Baltic } \\
\text { Corporation" }\end{array}$ & Passenger and freight air transport. & 296157.3 & 10668.0 & 121671.2 & 1053 & $99.80 \%$ \\
\hline $\begin{array}{l}\text { VAS "Latvijas } \\
\text { autoceḷu uzturētājs" }\end{array}$ & Maintenance of road network & 63843.3 & 1540.2 & 62967.4 & 1368 & $100 \%$ \\
\hline $\begin{array}{l}\text { AS “Pasažieru } \\
\text { vilciens }\end{array}$ & Rail passenger transport & 61731.7 & -1087.5 & 37073.0 & 965 & $100 \%$ \\
\hline $\begin{array}{l}\text { VAS “Starptautiskā } \\
\text { lidosta "Rīga"”" }\end{array}$ & $\begin{array}{l}\text { Aircraft, passenger and freight } \\
\text { services and airport maintenance }\end{array}$ & 44885.5 & 134.7 & 185610.2 & 1162 & $100 \%$ \\
\hline $\begin{array}{l}\text { VAS "Celu } \\
\text { satiksmes drošíbas } \\
\text { direkcija" }\end{array}$ & $\begin{array}{l}\text { Roadworthiness test, qualification } \\
\text { of drivers, registration of vehicles, } \\
\text { other services }\end{array}$ & 37284.7 & 1333.7 & 38795.8 & 610 & $100 \%$ \\
\hline $\begin{array}{l}\text { VAS "Latvijas gaisa } \\
\text { satiksme" }\end{array}$ & Air navigation services & 24631.3 & 215.1 & 30169.7 & 363 & $100 \%$ \\
\hline $\begin{array}{l}\text { VAS "Latvijas } \\
\text { Valsts celii” }\end{array}$ & Management of road infrastructure & 12132.2 & 43.6 & 5569.7 & 334 & $100 \%$ \\
\hline $\begin{array}{l}\text { VAS "Latvijas Jūras } \\
\text { administrācija" }\end{array}$ & $\begin{array}{l}\text { Maritime services, } \\
\text { state assigned functions }\end{array}$ & 4321.3 & 39.1 & 4625.6 & 149 & $100 \%$ \\
\hline $\begin{array}{l}\text { VSIA } \\
\text { "Autotransporta } \\
\text { direkcija" } \\
\end{array}$ & $\begin{array}{l}\text { Issue of licenses and permits in } \\
\text { transport industry }\end{array}$ & 3790.6 & 684.8 & 3520.0 & 92 & $100 \%$ \\
\hline $\begin{array}{l}\text { SIA „Eiropas } \\
\text { dzelzcel̦a linnijas” }\end{array}$ & $\begin{array}{l}\text { Development and management of } \\
\text { EU gauge rail infrastructure }\end{array}$ & 0.0 & -2.7 & 678.4 & 2 & $100 \%$ \\
\hline Total & & 989675.9 & 24730.0 & 491653.03 & 18414.0 & $100 \%$ \\
\hline
\end{tabular}

\section{Mandate}

"Ministry of Transport is a leading institution of state administration of transport and communication branches, which elaborates legal acts and policy planning documents regulating the branch. It provides the implementation of the transport policy" (www.sam.gov.lv).

In Latvia, the transport sectorial policy is set by the Ministry of Transport. The sector includes railways, road traffic, maritime and aviation, as well as passenger carriage and transit branches. The Ministry owns $100 \%$ of the shares in a number of major SOEs in this sector; CSCC (CrossSectoral Coordination Centre, 2015) is the control institution of state assets, as it is advised by international expert organisations.

As we can conclude from the table above, the share of SOEs assets are approaching half a billion EUR, and SOEs employ 18414 employees that is $35 \%$ of the number employed in all SOEs in Latvia. The share is down since VAS "Latvijas pasts", the national post service, is transferred in 2014 to the communication sector with 4189 employees and 94298.4 worth of assets compared with other resources. However, postal services are still included in Eurostat statistics under the transport and logistics industry (EC, 2012).

Upgrading public infrastructure and improving state-owned enterprise (SOE) governance are important elements of strengthening competitiveness.

Improving public infrastructure could also help attract FDI and associated technological know-how. Moreover, the current juncture is propitious for well-planned projects to attract centralised funding from the Juncker plan. An important area where reforms are both necessary and well-identified is ports: Riga and Ventspils ports both remain overly dependent on low-value added bulk traffic and face strong competition, especially from Russian ports. Staff urged speedy implementation of the recommendations of the World Bank study on ports, which made several specific suggestions to increase capacity and enhance connectivity to land transport, while improving governance and accountability. On a related front, centralising SOE management while divesting non-core activities - in line with long-planned reforms - would improve efficiency and accountability, contributing to an improvement in the business environment. The authorities note that a working group has been set up to consider the World Bank recommendations on ports, while a framework law to strengthen SOE governance was passed in October 2014. The latter will require a centralised SOE manager to be established, and independent boards and annual reporting will be reintroduced for largest SOEs (IMF, 2015), which is called "Cross-Sectoral Coordination Centre".

Taking into account the processes and increased need for transport services, globalisation, international trade in the environment of limited resources and complicated market conditions, the state task is not an easy, cited from OECD and the International Transport Forum publications.

Government's ability to provide infrastructure is inherently limited by the availability of resources.

"The provision of infrastructure is, therefore, always restricted by the scarcity of resources, meaning that all needs are not likely to be satisfied. Precisely because of these resource limitations, the pursuit of efficiency - i.e. the best 
possible use of available resources - is at the core of the decision regarding which model to employ for the provision of infrastructure. If infrastructure services are efficiently provided, society's resources are employed in the best possible way, satisfying, to the greatest extent, society's wants and needs" (OECD, 2008).

Transport industry can be divided in 4 groups: port operations (cargo), railway operations (cargo), road transport (cargo) and passenger transports, additionally storage and warehousing, air transport, pipelines.

According to statistics of Latvia in 2014, transport and storage made $10.0 \%$ of the national GDP, EU average around $5 \%$. Geographic location of 3 major ports and access to the Baltic Sea, and East-West transport corridor, rail gauge similar to CIS countries are some factors explaining such a high importance of transport industry. The trend is to face reduction of this industry's share in the national GDP mainly due to geopolitical reasons, global fossil resource prices, and fierce competition from other transit coridors in the region, particularly speedy development of Russian ports and infrastructure in Finnish Bay.
Well-developed ports (the authors agree that ports are essential and integral elements of Latvian transport infrastructure, but, according to the current legislation, ports are not SOEs, unlike in other Baltic States, i.e., Lithuania and Estonia), a decent road and railway network, and a postal and logistics service provide the backbone of the transportation sector's contribution to the Latvian economy. The continuous development of Riga International Airport, which has become the aviation hub of the Baltics, has greatly contributed to the growth of the transportation sector and indirect effect of other sectors.

The state plays a significant role in the sector. It is responsible for:

- Developing and maintaining the road network;

- Controlling the country's railway operator (Latvijas dzelzcelss), the postal service (Latvijas Pasts), and the international airport (Starptautiskā Lidosta Rìga); and

- Maintaining a controlling stake in the national airline Air Baltic Corporation (Mortensen, 2009).

TABLE III

PROVIDED SERVICES OF SOES FOR TRANSPORT INDUSTRY

(ADAPTED AND UPDATED BY THE AUTHORS FROM KRONBERGS \& CUKSTE (2012) AND MORTENSEN (2009)

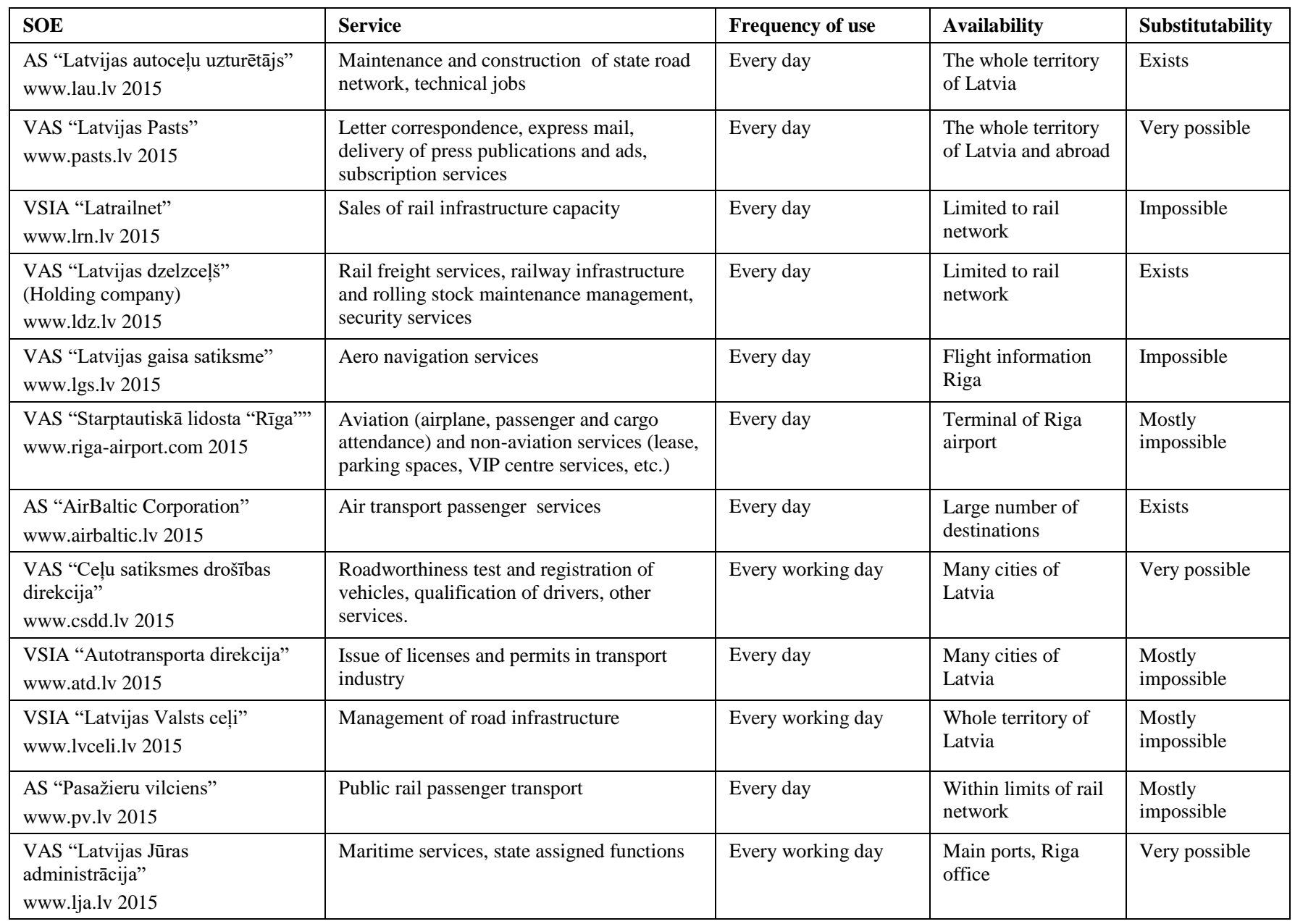


Fulfilling the state assigned tasks (social benefits) and receiving the state funding, the SOEs provide the public services, which could not be provided by private companies at such price, in such quality and quantity.

Significant part of the services is provided in the whole territory of Latvia; rates are established by SOE boards, and competition either already exists or is highly possible.

Some services are limited to territory of particular infrastructure, and rates are determined by the Cabinet of Ministers, the substitution and replacement of services is hardly possible (Kronbergs \& Cukste, 2012).

There are also 4 state agencies in the Latvian transport industry, under supervision of the Ministry of Transport:

- State Railway Inspection (Valsts dzelzcel̦a tehniskā inspekcija); www.vdzti.lv;

- Civil Aviation Agency (Civilās aviācijas aǵentūra); www.caa.lv;

- Transport Accident and Incident Investigation Office (Transporta nelaimes gadījumu un incidentu izmeklēšanas birojs); www.taiib.lv;

- State Railway Administration (Valsts dzelzceḷa administrācija); www.vda.gov.lv.

The state agencies are included only for informative purposes in order to understand the different objectives and tasks delegated by the state in the industry.

\section{METHODOLOGY OF RESEARCH}

Exploratory research, synthesis and categorising are the main scientific methods used during the writing of this article. The literature research was conducted to discover the SOE specific issues: governance, performance, political and business environment in SOE dominated industries.

Main practice differences and preconditions of SOEs, which are typical of state controlled industries, were considered in the research. From more than 140 Latvian SOEs 11 operating in the transport industry under supervision of the Ministry of Transport were selected, short company profiles were summarised, primary and secondary data, definitions, concepts and their evolutions were collected.

The analysis of main services provided was performed, and possibility of substitution by private companies was evaluated in case of liberalisation efforts enhanced by OECD and IMF recommendations.

The basic idea behind the SOE service analysis was to distinguish between commercial and non-commercial activities, as well as between core functions of SOEs and auxiliary functions not typical of the strategic SOE, which should be kept under state ownership, or at least control.

The limitations are that there is limited public information available of commercial/non-commercial services and objectives.

\section{FINDINGS / RESULTS}

SOEs are containing a large part of OECD countries with GDP around $6 \%$, but Latvia is leading that benchmark by approximately $18 \%$, and the main industries are natural resources, infrastructure, utilities, transportation, and telecommunications. As stated in the literature review, ownership itself is not the threat to the efficiency, but market conditions and state regulations are preconditions of low performance, efficiency and competitiveness as a norm of specific SOE operating environment.

SOEs in Latvia are under constant public pressure for transparency and performance, market distortions and influence on business environment in the industry. An increase in competition increases the quality and reduces costs according to research in the area, although there is not a consensus among researchers about SOE performance, effectiveness in comparison with POE under the same circumstances (market, product, regulatory framework, governance). There is significantly larger public sector employment (32\%) than in the OECD (an average of $22 \%$ ), which also explains larger impact in the transport industry dimension.

There are 11 SOEs in the Latvian transport industry, according to CSCC information in Table II. As it is mentioned in the OECD and other resources, SOE annual reports and strategy objective-performance documents are very rarely publicly available, although in general they are owned by the citizens.

Most common SOE services are analysed, according to the literature review in Table III; there is very limited research in this area: SOE service market analysis, especially construction, maintenance, security efficiency, strategic development, possible internationalisation in other markets. There is empirical evidence that transport and transport infrastructure services are bundled together commercial ones with non-commercial/social and profitable with loss making. State ownership and control provides the employment, political influence in the industry through political allies that results in notorious path of legal allegations, corrupt procurement practices, inefficient corporate structures and use of resources through public funding particularly in shortage in roads and rail infrastructure, ports. The ports are under jurisdiction of derived state corporations unlike in other Baltic States, and according to World Bank report (2013), Latvian port sector reveals three major issues which have affected management practices currently being used in the ports and competitiveness of the ports: lack of independence due to political appointees, weak collective accountability and limited transparency in decision making. Due to unknown reasons, the topic of state involvement and control of transport industry has not received adequate attention from stakeholders and policy makers despite the remarks from international organisations urging for reforms of public sector corporations.

Conclusions on SOE services and their evaluation could provide ground for further research in the area of SOE sustainability and competitiveness issues in the transport industry. 


\section{REFERENCES}

Aharoni, Y. (1981). Performance evaluation of state-owned enterprises: A process perspective. Management Science, 27(11), 1340-1347. http://dx.doi.org/10.1287/mnsc.27.11.1340

Aharoni, Y. (2000.) The performance of state-owned enterprises. In P. A. Toninelli (Ed.), The rise and fall of state-owned enterprise in the Western world (pp. 49-72). Cambridge: Cambridge University Press. http://dx.doi.org/10.1017/cbo9780511896798.004

Alison, C. \& Kohler, P. (2005). Property law: commentary and materials. Cambridge University Press. p. 40 http://dx.doi.org/10.1017/CBO9781139051941.003

Baltic Institute of Corporate Governance. (2012) Governance of State owned enterprises in Baltic States. Retrieved Sept. 25, 2015, from http://www.ifc.org/wps/wcm/connect/a69fbc00446b373cb109bdc66d9c7 28b/Kristian+Kaas+Mortensen.pdf?MOD=AJPERES

Basu, K. (2008). China and India and world recession. BBC News. Retrieved Sept. 15, 2015, from http://news.bbc.co.uk/2/hi/south_asia/7733797.stm

Boycko, M. Shleifer, A. \& Vishny, R. W. (1996). A Theory of Privatization Economic Journal, 106(435), 309-319. http://dx.doi.org/10.2307/2235248

Boycko, M., Shleifer, A. \& Vishny, R. (1997). Privatizing Russia. Cambridge: MIT Press.

Bortolotti, B. \& Faccio, M. (2009). Government control of privatized firms. Review of Financial Studies, 22(8), 2907-2939. http://dx.doi.org/10.1093/rfs/hhn077

Carnegie, G. \& West, B. (2005). Making accounting accountable in the public sector. Critical Perspectives on Accounting, 16(7), 905-928. http://dx.doi.org/10.1016/i.cpa.2004.01.002

Calderon, C. \& Serven, L. (2003). The Output Cost of Latin America's Infrastructure Gap. In Easterly, W. \& Servén, L. (Ed.), The Limits of Stabilization: Infrastructure, Public Deficits, and Growth in Latin America. (pp. 95-118). Stanford University Press and the World Bank.

Caves, D. W. \& Christensen, L. R. (1980). The Relative Efficiency of Public and Private Firms in Competitive Environment: The Case of Canadian Railroads. Journal of Political Economy, 88(5), 958-976. http://dx.doi.org/10.1086/260916

Christiansen, H. (2011). The Size and Composition of the SOE Sector in OECD Countries. OECD Corporate Governance Working Papers, No. 5 , OECD Publishing. http://dx.doi.org/10.1787/5kg54cwps0s3-en

Cuervo-Cazurra, A. \& Dau, L. A. (2009). Pro market reforms and firm profitability in developing countries. Academy of Management Journal, 52(6), 1348-1368. http://dx.doi.org/10.5465/AMJ.2009.47085192

Cross-Sectoral Coordination Centre. (n.d.). Retrieved May 1, 2016, from www.pkc.gov.lv

D’Souza, J. \& Megginson, W. (1999), The Financial and Operating Performance of Privatized Firms During the 1990s. Journal of Finance, 54(4), 1397-1438. http://dx.doi.org/10.1111/0022-1082.00150

Dewenter, K. L. \& Malatesta, P. H. (2001). State-Owned and privately Owned Firms: An Empirical Analysis of Profitability, Leverage, and Labor Intensity. The American Economic Review, 91(1), 320-334. http://dx.doi.org/10.1257/aer.91.1.320

EBRD. (2013). Transport sector strategy document of the European bank for reconstruction and development.

Economist. (2012, Jan. 21). Special report: State capitalism, 1-18.

Estache, A. (2006). Infrastructure: A survey of recent and upcoming issues. The World Bank, Mimeo, April 2006. (version 2.0).

Flynn, N. (2002). Explaining new public management: The importance of context. In McLaughlin K., Osborne, S. \& Ferlie, E. (Eds.), New public management: Current trends and future prospects (pp. 57-76). London: Routledge.

Graham, A. (1997). The UK 1979-95: Myths and Realities of Conservative Capitalism. In Crouch, C. \& Streeck, W. (Eds.), Political Economy of Modern Capitalism, London: Sage, 117-132. http://dx.doi.org/10.4135/9781446217849.n7

Grout, P. A. \& Martin, S. (2003). The Assessment: Financing and Managing Public Services. Oxford Review of Economic Policy, 19(2), 215-234. http://dx.doi.org/10.1093/oxrep/19.2.215

Horizon 2020 - Work Programme (2014-2015). (n.d.). Smart, green and integrated transport, pp. 57. Retrieved Sept. 30, 2015, from http://ec.europa.eu/programmes/horizon2020/en/h2020-section/smartgreen-and-integrated-transport

Hou, W. \& Moore, G. (2011). Player and referee roles held jointly: The effect of state ownership on China's regulatory enforcement against fraud. Journal of Business Ethics, 95, 317-335. http://dx.doi.org/10.1007/s10551-011-0858-1
IMF Country Report. (2015). No. 15/110, Republic of Latvia Article IV Consultation - staff report; informational annex and press release.

Karnitis E. \& Virtmanis, A. (2011). Multi-sectoral regulation of services of general economic interest - Ten year experience of Latvia. Public Utilities Commission of Latvia: Riga.

Kole, S. R. \& Mulherin H. J. (1997). The Government as a Shareholder: A case from the United States. The Journal of Law and Economics, 40(1), 1-22. http://dx.doi.org/10.1086/467364

Kowalski, P., Buge, M., Sztajerowska, M. \& Egeland, M. (2013). StateOwned Enterprises: Trade Effects and Policy Implications. OECD Trade Policy Papers, No. 147, OECD Publishing, 35. http://dx.doi.org/10.1787/5k4869ckqk71-en

Kronbergs \& Cukste. (2012). Advokata biroja 4. nodevums Valsts kancelejas konkursa "Publiskās personas dalības kapitālsabiedrībā mērka, nepieciešamības un statusa kritēriju izvērtējums" Starpziñojums par valsts dalības kapitālsabiedrībās analīzi, Riga, 142-143.

Lane, J. E. (2000). New public management. London: Routledge.

Lawson, C. (1994). The theory of state-owned enterprises in market economies. Journal of Economic Surveys, 8(3), 283-309. http://dx.doi.org/10.1111/j.1467-6419.1994.tb00104.x

Levy, B. (1987). A theory of public enterprise behavior. Journal of Economic Behavior and Organization, 8(1), 75-96. http://dx.doi.org/10.1016/0167-2681(87)90022-9

Lindsay, C. M. (1976). A theory of government enterprise. Journal of Political Economy, 84(5), 1061-1077. http://dx.doi.org/10.1086/260496

Lin, L.-W. \& Milhaupt, C. J. (2011). We are the (national) champions: Understanding the mechanisms of state capitalism in China. Columbia Law and Economics Working paper, New York: Columbia University School of Law. http://dx.doi.org/10.2139/ssrn.1952623

Ministry of Economy (2014). Economic Development of Latvia Report, June 2014, p. 29.

Ministry of Economy (2013). Economic Development of Latvia Report, June 2013, p. 28

Megginson, M. \& Netter, J. (2001). From State to Market: A Survey of Empirical Studies on Privatization. Journal of Economic Literature, 39(2), 321-389. http://dx.doi.org/10.1257/jel.39.2.321

Morris, M. H. \& Kuratko, D. F. (2002). Corporate Entrepreneurship, Fort Worth: Harcourt College Publishers.

Mortensen, K. K. (2009). Annual review of State owned assets. Baltic Institute of Corporate Governance.

Munnell, A. H. (1990a). Why has productivity growth declined? Productivity and public investment. New England Economic Review, January/February, 3-22. Retrieved Sept. 15, 2015, from http://www.bostonfed.org/economic/neer/neer1990/neer190a.pdf

Munnell, A. H., (1990b). How does public infrastructure affect regional economic performance? New England Economic Review, September/October, 11-32. Retrieved Sept. 15, 2015, from https://www.bostonfed.org/economic/neer/neer1990/neer590b.pdf

North, D. C. (1990). Institutions, institutional change, and economic performance. New York: Norton. http://dx.doi.org/10.1017/CBO9780511808678

OECD. (2005). Guidelines of the Corporate Governance of State-Owned Enterprises.

OECD. (2005). OECD, Corporate Governance of State-Owned Enterprises: A Survey of OECD Countries Organization for Economic Co-operation and Development. Paris.

OECD. (2003). Report on Non-Commercial Service Obligations and Liberalisation.

OECD. (2015). Review of the Corporate Governance of State-Owned Enterprises Latvia.

OECD. (2010). State-Owned Enterprises and the Principle of Competitive Neutrality. OECD Publishing, 26-27.

OECD. (2014). The size and Sectoral Distribution of SOEs in OECD and Partner Countries. OECD Publishing.

OECD. (2008). Transport Infrastructure Investment: Options for Efficiency. OECD Publishing, p. 36.

Okhmatovskiy, I. (2010). Performance implications of ties to the government and SOEs: A political embeddedness perspective. Journal of Management Studies, 47(6), 1020-1047. http://dx.doi.org/10.1111/j.1467-6486.2009.00881.x

Osborne, D. \& Gaebler, T. (1992). Reinventing government: How the entrepreneurial spirit is transforming the public sector. AddisonWesley, Reading.

Perotti, E. (1995). Credible Privatization. American Economic Review, 85(4), $847-859$. 
Pryke, R. (1982). The Comparative Performance of Public and Private Enterprise. Fiscal Studies, 3(2), 68-81. http://dx.doi.org/10.1111/j.1475-5890.1982.tb00572.x

Puffer, S. M., \& McCarthy, D. J. (2007). Can Russia's state-managed, network capitalism be competitive? Institutional pull versus institutional push. Journal of World Business, 42(1), 1-13. http://dx.doi.org/10.1016/j.jwb.2006.08.008

Sahoo, P. \& Dash, R. K. (2008). Economic Growth in South Asia: Role of Infrastructure with. Institute of Economic Growth Working paper, No. 288.

Sahoo, P. \& Dash, R. K. (2009). Infrastructure Development and Economic Growth in India, Journal of the Asia Pacific Economy, 14 (4), 351-365. http://dx.doi.org/10.1080/13547860903169340

Savas, E. (1981). Alternative Institutional Models for the delivery of public services. Public Budgeting and Finance, Winter, 12-20. http://dx.doi.org/10.1111/1540-5850.00533

Sheshinski, E. \& López-Calva, L. F. (2003). Privatization and its Benefits: Theory and Evidence. CESifo Economic Studies, 49(3), 429-459. http://dx.doi.org/10.1093/cesifo/49.3.429

Shirley, M. M. \& Walsh, P. (2000). Public versus Private Ownership: The Current State of the Debate. Policy Research Working Papers, World Bank, Washington. http://dx.doi.org/10.1596/1813-9450-2420

Shleifer, A. \& Vishny, R. W. (1997). A Survey of Corporate Governance. Journal of Finance, 52(2), 737-783. http://dx.doi.org/10.1111/j.1540-6261.1997.tb04820.x

Shirley, M. (1991). Evaluating the Performance of State-Owned Enterprises in Pakistan. In Ramamurti, R. \& Vernon, R. (Eds.), Privatization and Control of State-Owned Enterprises, (pp. 234-278). Washington, D.C.: The World Bank, EDI Development Studies.

Shirley, M. (1999). Bureaucrats in Business: The Role of Privatization versus Corporatization in State-Owned Enterprise Reform. World Development, 27(1), 115-136. http://dx.doi.org/10.1016/S0305-750X(98)00130-2

Shleifer, A. \& Vishny, R. W. (1994). Politicians and firms. Quarterly Journal of Economic, 109(4), 995-1025. http://dx.doi.org/10.2307/2118354

Shleifer, A. (1998). State versus Private Ownership. Journal of Economic Perspectives, 12(4), 133-150. http://dx.doi.org/10.1257/jep.12.4.133

Short, R. P., (1984). The role of public enterprises: An International Statistical Comparison. In Floyd, R. H., Gray, C. S. \& Short, R. P. (Eds.), Public Enterprises in Mixed Economies: Some Macroeconomic Aspects, (pp. 110-181). Washington D.C.: IMF.

Stiglitz, J. E. (1988). Economics of the Public Sector, (2nd ed.). London: Norton \& Company.

Talbot, C. (2001). UK Public Services and Management (1979-2000): Evolution or Revolution? International Journal of Public Sector Management, 14(4), 281-303. http://dx.doi.org/10.1108/09513550110396318

Tan, J. (2002). Culture, nation, and entrepreneurial strategic orientations: implications for an emerging economy. Entrepreneurship Theory and Practice, 26(4), 95-111. http://dx.doi.org/10.2139/ssrn.1552182

Toninelli, P. A. (2000). The Rise and Fall of Public Enterprise: The Framework. In Toninelli, P. A. (Ed.), The Rise and Fall of State-Owned Enterprise in the western World, (pp. 3-24). Cambridge University Press. http://dx.doi.org/10.1017/CBO9780511896798.002

Vickers, J. (1995). Concepts of Competition. Oxford Economic Papers, 47(1), 1-23. Retrieved from http://www.jstor.org/stable/2663661

Vickers, J. \& Yarrow, G. (1988). Privatization: An Economic Analysis. Cambridge: MIT Press.

Vickers, J. \& Yarrow, G. (1989). Privatization: An Economic Analysis. Cambridge: MIT Press.

Walsh, K. (1995). Public Services and Market Mechanisms: Competition, Contracting and the New Public Management. London: Macmillan. http://dx.doi.org/10.1007/978-1-349-23979-5

Wengenroth, U. (2000). The rise and fall of state-owned enterprise in Germany. In Toninelli, P. M. (Ed.). The Rise and Fall of State-Owned Enterprise in the Western World, (pp. 103-127). Cambridge: Cambridge University Press. http://dx.doi.org/10.1017/cbo9780511896798.006

World Bank. (1995). Bureaucrats in Business: The Economics and Politics of Government Ownership.

World Bank. (1994). World Development Report 1994: Infrastructure for development. New York: Oxford University Press. http://dx.doi.org/10.1596/978-0-1952-0992-1

World Bank. (2013). Review of port sector of Latvia: Competitiveness and governance Final report.

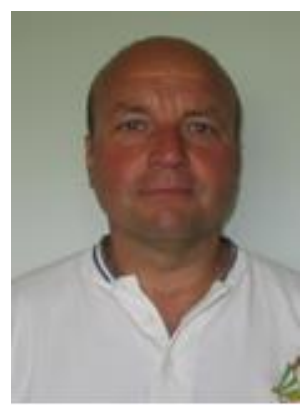

Māris Plūmiṇš is 1st-year Doctoral student at RTU. He received the Master's degree from RTU in 1999, and MBA from Kennesaw State University in 2002. His field of research includes competitiveness and sustainability of state-owned enterprises.

July 2013 - Aug. 2014, Area Sales Manager, Latvia, Russia, IS countries at Stena Line. The Stena Line Freight routes' network is one of Europe's largest linking key ports and road connections across Northern Europe.

Sept. 2011 - April 2013, Managing Director at RCT Logistics Ltd. and authorised representative of Reefer Cargo Terminal Ltd., frozen product warehouse terminal. Oct. 2009 - present (on contract basis), Lecturer at Ventspils University College on subject "Transport and Logistics Networks in Baltic Sea Region"; "Logistics Basics" for senior level students.

Feb. 2006 - Apr. 2009, Office/Sales Manager at Scandlines Deutschland $\mathrm{GmbH}$ (ferry cargo multimodal RoRo solutions) representative office in Latvia, Ventspils

E-mail: mplumins@yahoo.com

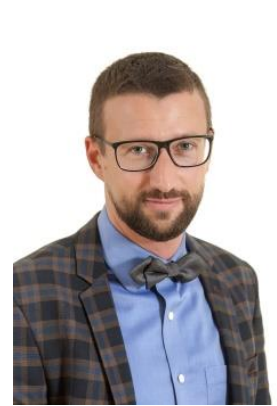

Dr. Deniss Ščeulovs is an Assistant Professor at the Faculty of Engineering Economics and Management of Riga Technical University (Latvia). Field of research: Electronic environment and entrepreneurship, small business organisation. Dr. Ščeulovs participated as a Researcher and Leader in the EU and in international scientific projects. Deniss Ščeulovs regularly participates in international teaching and exchange programmes and lecturing abroad. Dr. Ščeulovs organised and participated in business and educational seminars and workshops. Deniss Ščeulovs has practical skills and experience in modern business environment working as a Marketing Director at LATSIGN Ltd. Dr. Ščeulovs has more than 50 publications in scientific and business literature. Since 2010 Dr. Ščeulovs has participated in more than 30 international scientific conferences with reports. He has been lecturing at Riga Technical University and abroad: E-Commerce and E-Entrepreneurship; IT in Human Resources Management; Product Marketing Politics; SME's Entrepreneurship and Business Organisation. He has been assisting in the course "New Product Design and Development”. Dr. Ščeulovs has more than 10 years of experience in business consulting (marketing, e-commerce).

E-mail: deniss.sceulovs@rtu.lv 